\title{
Pengaruh Pengungkapan Akuntansi Sumber Daya Manusia dalam Laporan Keuangan terhadap Kinerja Keuangan Perusahaan
}

(Studi Kasus Pada PG. Modjopanggoong Tulungagung)

\author{
Siti Isnaniati \\ Universitas Islam Kadiri \\ Isnaniati_3011@yahoo.co.id
}

\begin{abstract}
The influence of human resource accounting disclosures in the financial statements of company's financial performance (case study at the Modjopanggoong Tulungagung Sugar Factory) aims to determine the effect of human resource accounting disclosures in the financial statements of the financial performance of the company. The data analysis technique quantitative and analysis tool used are (HRCA) Human Resource Cost Accounting, (ROA) Return On Asset, (ROE) Return On Equity, (ATO) Asset Turn Over. The results showed by implementing human resources accounting will affect the financial statements with the increase in total assets, total equityand total profit and decrease in losses. There is an increase in the percentage of $R O$ and $R O E$, but there is a decrease for ATO.
\end{abstract}

\begin{abstract}
ABSTRAK
Pengaruh Pengungkapan Akuntansi Sumber Daya Manusia Dalam Laporan Keuangan Terhadap Kinerja Keuangan Perusahaan (Studi Kasus pada PG. Modjopanggoong Tulungagung) bertujuan untuk mengetahui pengaruh pengungkapan akuntansi sumber daya manusia dalam laporan keuangan terhadap kinerja keuangan perusahaan. Tehnik analisis data yang digunakan adalah deskriptif kuantitatif dan alat analisis yang digunakan adalah analisis HRCA (Human Resource Cost Accounting), ROA (Return On Asset), ROE (Return On Equity), dan ATO (Asset Turn Over). Hasil penelitian menunjukkan dengan melakukan penerapan akuntansi sumber daya manusia maka akan berpengaruh pada laporan keuangan dengan meningkatnya total aset, total ekuitas dan jumlah laba serta penurunan rugi. Terdapat kenaikan prosentase ROA dan ROE, tetapi terjadi penurunan untuk ATO.
\end{abstract}

Kata kunci : Akuntansi Sumber Daya Manusia, Laporan Keuangan, Kinerja Keuangan.

\subsection{Latar Belakang}

\section{PENDAHULUAN}


Tujuan utama perusahaan beraktivitas adalah mendapatkan keuntungan maksimal. Setiap menjalankan aktivitas usahanya pasti tidak lepas dari keterlibatan para karyawan. Dalam melakukan pekerjaan para karyawan mengeluarkan kemampuan, pikiran, dan tenaga demi tercapainya cita-cita perusahaan. Semua yang telah dikeluarkan oleh para karyawan adalah suatu sumber daya manusia yang dimiliki oleh perusahaan. Sumber daya manusia merupakan energi yang istimewa berfungsi sebagai input kerja yang akan menghasilkan nilai bagi perusahaan. Apabila perusahaan mengakui sumber daya manusia sebagai harta maka perusahaan menerapkan akuntansi sumber daya manusia. Akuntansi sumber daya manusia menggambarkan suatu investasi berupa ukuran kemampuan manusia yang dimiliki perusahaan. Biaya-biaya yang dikeluarkan untuk kegiatan-kegiatan seperti penarikan, seleksi yang selektif, pengembangan berupa pendidikan, dan pelatihan dikapitalisasi sebagai aset dan mengamortisasinya. Beberapa perusahaan ada yang menyadari bahwa sumber daya manusia sebagai aset dalam perusahaan, namun perusahaan tidak mengungkapkannya dalam laporan keuangan. Laporan keuangan yang disajikan harus memenuhi syarat kewajaran dan jujur sesuai standar keuangan yang berlaku di Indonesia, karena laporan keuangan tersebut dibaca dan dipakai dalam pengambilan keputusan ekonomi. Salah satu cara membaca laporan keuangan yaitu dengan melakukan analisis kinerja keuangan. Kinerja keuangan merupakan gambaran kondisi keuangan dari perusahaan dalam mencapai keberhasilan sebagai hasil yang telah dicapai dari segala aktivitas pada periode tertentu dengan indikator kecukupan modal, likuiditas dan profitabilitas. PG. Modjopanggoong merupakan perusahaan manufaktur yang bertempat di Kabupaten Tulungagung. Produksi utamanya adalah gula pasir dan terdapat produk sampingan berupa tetes. Dalam operasional perusahaan tentunya dijalankan oleh karyawankaryawan yang profesional dan ahli dalam bidangnya. Demi menunjang hal tersebut pihak perusahaan melakukan pengadaan peningkatan kualitas sumber daya manusia seperti perekrutan, pendidikan, dan pelatihan karyawan. Biaya-biaya yang dikeluarkan untuk kegiatan pengembangan kualitas sumber daya manusia tersebut oleh perusahaan diakui dan disajikan dalam laporan laba rugi sebagai biaya dan tidak diungkapkan dalam laporan keuangan sebagai aset.

\subsection{Batasan Penelitian}

Agar penelitian ini tidak meluas maka peneliti membatasi permasalahan hanya pada pengaruh pengungkapan akuntansi sumber daya manusia dalam laporan keuangan terhadap kinerja keuangan perusahan

dan menggunakan data laporan keuangan perusahaan yang meliputi: 1aporan laba rugi tahun 2016-2018, laporan neraca tahun 2016-2018 PG. Modjopanggoong untuk menghitung kinerja keuangan menggunakan ROA (Return On Asset), ROE (Return On Equity), ATO (Asset Turn Over).

\subsection{Tujuan Penelitian}

Tujuan diadakannya penelitian ini adalah untuk menganalisis pengaruh pengungkapan akuntansi sumber daya manusia dalam laporan keuangan terhadap kinerja keuangan perusahaan. 


\section{METODOLOGI PENELITIAN}

\subsection{Teknik Analisis Data}

Teknik analisis yang digunakan berupa analisis deskriptif kuantitatif. Alat analisis penelitian ini menggunakan metode perhitungan HRCA (human resource cost accounting), perhitungan kinerja keuangan ROA (Return On Asset), ROE (Return ON Equity), dan ATO (Asset Turn Over) sebelum dan sesudah penerapan akuntansi sumber daya manusia.

Metode HRCA (human resource cost accounting) menghitung biaya perekrutan dan pengembangan karyawan selama 3 tahun dan diakumulasi menjadi aset yaitu aset sumber daya manusia.

Investasi in HRA (Human Resource Accounting) :

Acquistion cost $\quad \mathrm{xxx}$

Development cost $\quad \underline{\mathrm{xxx}}+$

Keterangan :

Acquistion cost adalah biaya perekrutan dan seleksi karyawan. Development cost terdiri dari biaya pendidikan dan pelatihan karyawan.

Mengamortisasi aset sumber daya manusia untuk periode waktu yang sama akan diamortisasi selama umur manfaat yaitu 5 tahun menggunakan metode garis lurus. Amortisasi $=$ Total Aset Sumber Daya Manusia

Menentukan nilai buku bersih aset sumber daya manusia dihitung dengan menggunakan rumus sebagai berikut :

Aset Sumber Daya Manusia -

Akumulasi Amortisasi Sumber

Daya Manusia

Nilai buku bersih aset sumber daya manusia disajikan dalam laporan neraca. Membuat jurnal penyesuaian untuk menyesuaikan akuntansi sumber daya manusia a. Jurnal untuk mencatat pengakuan biaya sumber daya manusia

Investasi Sumber Daya Manusia

$\mathrm{xxx}$

Kas

$\mathrm{XXX}$

b. Jurnal untuk mencatat beban amortisasi sumber daya manusia

Beban Amortisasi SDM xxx

Aset Sumber Daya Manusia xxx

Menyusun laporan keuangan setelah menerapkan aset sumber daya manusia. Dalam menyusun laporan keuangan ini peneliti menyusun laporan keuangan yang telah mengakui adanya investasi sumber daya manusia pada laporan neraca dan mengakui adanya beban amortisasi sumber daya manusia pada laporan laba rugi perusahaan. 


\section{Perhitungan Kinerja Keuangan}

$$
\text { ROA }=\frac{\text { Laba bersih }}{\text { Total Aktiva }}
$$

$\mathrm{ROE}=\frac{\text { Earning After Interest and Tax }}{\text { Equity }}$

$\mathrm{ATO}=\quad \frac{\text { Penjualan }}{\text { Total Aktiva }}$

Tabel 2.1

Perhitungan Kinerja Keuangan Tahun 2016

\begin{tabular}{|l|l|l|}
\hline Kinerja Keuangan & \multicolumn{1}{|c|}{ Sebelum Penerapan ASDM } & \multicolumn{1}{c|}{ Sesudah Penerapan ASDM } \\
\hline \multirow{2}{*}{ ROA } & $\begin{array}{l}16.618079 .000: 130.090 .326 .618 \\
=0,127743=12,77 \%\end{array}$ & $\begin{array}{l}17.297 .367 .800: 130.769 .615 .418 \\
=0,132274=13,23 \%\end{array}$ \\
\hline \multirow{2}{*}{ ROE } & $\begin{array}{l}16.618079 .000: 89.861 .485 .185 \\
=0,18493=18,49 \%\end{array}$ & $\begin{array}{l}17.297 .367 .800: 90.540 .773 .985 \\
=0,191045=19,10 \%\end{array}$ \\
\hline \multirow{2}{*}{ ATO } & $\begin{array}{l}81.357 .967 .000: 130.090 .326 .618 \\
=0,625396=0,625 \mathrm{kali}\end{array}$ & $\begin{array}{l}81.357 .967 .000: 130.769 .615 .418 \\
=0,622147=0,622 \mathrm{kali}\end{array}$ \\
\hline
\end{tabular}

Tabel 2.2

Perhitungan Kinerja Keuangan Tahun 2017

\begin{tabular}{|l|l|l|}
\hline Kinerja Keuangan & \multicolumn{1}{|c|}{ Sebelum Penerapan ASDM } & \multicolumn{1}{c|}{ Sesudah Penerapan ASDM } \\
\hline \multirow{2}{*}{ ROA } & $\begin{array}{l}43.675 .126 .000: 116.753 .920 .009 \\
=0,374078=37,41 \%\end{array}$ & $\begin{array}{l}44.473 .943 .800: 118.401 .848 .809 \\
=0,375619=37,56 \%\end{array}$ \\
\hline \multirow{2}{*}{ ROE } & $\begin{array}{l}43.675 .126 .000: 92.517 .971 .639 \\
=0,472072=47,21 \%\end{array}$ & $\begin{array}{l}44.473 .943 .800: 94.165 .900 .439 \\
=0,472294=47,23 \%\end{array}$ \\
\hline \multirow{2}{*}{ ATO } & $\begin{array}{l}140.976 .438 .000: 116.753 .920 .009 \\
\text { NT }\end{array}$ & $\begin{array}{l}140.976 .438 .000: 118.401 .848 .809 \\
=1,207466=1,207 \mathrm{kali}\end{array}$ \\
\hline
\end{tabular}

Tabel 2.3

Perhitungan Kinerja Keuangan Tahun 2018

\begin{tabular}{|l|l|l|}
\hline $\begin{array}{l}\text { Kinerja } \\
\text { Keuangan }\end{array}$ & Sebelum Penerapan ASDM & Sesudah Penerapan ASDM \\
\hline ROA & $\begin{array}{l}(27.061 .083 .000): 274.660 .393 .518 \\
=(0,09853)=-9,85 \%\end{array}$ & $\begin{array}{l}(26.913 .117 .200): 276.868 .270 .318 \\
=(0,09721)=-9,72 \%\end{array}$ \\
\hline ROE & $\begin{array}{l}(27.061 .083 .000): 253.420 .546 .367 \\
=(0,10678)=-10,68 \%\end{array}$ & $\begin{array}{l}(26.913 .117 .200): 255.628 .423 .167 \\
=(0,10528)=-10,53 \%\end{array}$ \\
\hline ATO & $\begin{array}{l}59.415 .836 .000: 274.660 .393 .518 \\
=0,216325=0,216 \mathrm{kali}\end{array}$ & $\begin{array}{l}59.415 .836 .000: 276.868 .270 .318 \\
=0,2146=0,215 \mathrm{kali}\end{array}$ \\
\hline
\end{tabular}

Terdapat kenaikan total aset pada tahun 2016 sebesar Rp 679.288.800,00 tahun 2017 sebesar Rp. 1.647.928.800,00 dan tahun 2018 sebesar Rp. 2.207.876.800,00 dikarenakan adanya kapitalisasi harga perolehan sumber daya manusia yang semula dicatat sebagai biaya dicatat menjadi aset bersih sumber daya 
manusia. Total ekuitas tahun 2016 naik sebsar Rp. 679.288.800,00. Untuk tahun 2017 total ekuitas terdapat kenaikan sebesar Rp. 1.647.928.800,00 sedangkan untuk tahun 2018 total ekuitas naik sebesar Rp. 2.207.876.800,00. Kenaikan tersebut dikarenakan adanya penyisihan modal sumber daya manusia pada neraca bagian pasiva. Total laba tahun 2016 terdapat kenaikan laba sebesar Rp. 679.288.800,00. Pada tahun 2017 kenaikan laba sebesar Rp. 798.817.800,00. Tahun 2018 penurunan kerugian sebesar Rp. 147.965.800,00. Kenaikan laba atau penurunan kerugian dikarenakan harga perolehan sumber daya manusia yang semula menjadi biaya dikapitalisasi menjadi aset bersih sumber daya manusia. Analisis hasil perhitungan dengan menerapkan akuntansi sumber daya manusia pada penyajian laporan keuangan dan pengaruhnya terhadap kinerja keuangan ROA, ROE, dan ATO yaitu : Pada tahun 2016 hasil perhitungan ROA terdapat kenaikan 0,46\%, kenaikan tersebut disebabkan adanya peningkatan total aset sebesar Rp. 679.288.800,00 dan peningkatan laba sebesar Rp. 679.288.800,00. Hasil perhitungan ROE naik sebesar $0,61 \%$ selisih tersebut dikarenakan adanya peningkatan ekuitas sebesar Rp. 679.288.800,00. Hasil perhitungan ATO sebelum dan sesudah ASDM tetap yaitu 0,625 kali, tidak terdapat selisih sebelum dan sesudah penerapan akuntansi sumber daya manusia, tidak adanya selisih ini dikarenakan kenaikan total aset hanya sebesar Rp. 679.288.800,00 sementara total penjualan tetap. Pada tahun 2017 hasil perhitungan ROA naik 0,15\%, kenaikan tersebut muncul karena adanya kenaikan total aset sebesar Rp. 1.647.928.800,00 dan kenaikan laba yaitu sebesar Rp. 798.817.800,00. Hasil perhitungan ROE terdapat kenaikan $0,02 \%$. Kenaikan tersebut naik karena adanya penambahan total ekuitas sebesar Rp. 1.647.928.800,00. Hasil perhitungan ATO terdapat penurunan Rp. 0,02 sebelum dan sesudah penerapan akuntansi sumber daya manusia penurunan tersebut dikarenakan adanya kenaikan total aset sebesar Rp. 1.647.928.800,00 sementara total penjualan tetap. Pada tahun 2018 hasil perhitungan ROA terdapat penurunan selisih rugi sebesar $0,13 \%$ karena adanya kenaikan total aset sebesar Rp. 2.207.876.800,00 dan penurunan kerugian sebesar Rp. 147.965.800,00. Hasil perhitungan ROE terdapat selisih penurunan ekuitas sebesar $0,15 \%$, selisih tersebut disebabkan adanya kenaikan ekuitas sebesar Rp. 2.207.876.800,00. Hasil perhitungan ATO terdapat selisih Rp. 0,01 sebelum dan sesudah penerapan akuntansi sumber daya manusia. Selisih dikarenakan adanya kenaikan total aset sebesar Rp. 2.207.876.800,00 sementara total penjualan tetap.

\section{Saran}

Berdasarkan uraian kesimpulan di atas, maka peneliti memberikan saran kepada PG. Modjopanggoong Tulungagung sebaiknya perusahaan menggunakan akuntansi sumber daya manusia dimana biaya pendidikan dan pelatihan karyawan dikapitalisasi menambah aset sebagai Net Investment in Human Resource (Aset Bersih SDM) serta diletakkan di kelompok aset tak berwujud (Intangible Asset), hal ini disebabkan :

1. Jika perusahaan menggunakan akuntansi sumber daya manusia maka dalam pembuatan laporan keuangan akan lebih realistis, sehingga akan membantu dalam pengambilan keputusan. 
2. Dapat memperbaiki kelemahan dari kinerja keuangan ROA, dengan meningkatnya total aset dan berkurangnya biaya sehingga laba bertambah.

\section{DAFTAR PUSTAKA}

Belkaoui, Ahmed Riahi . 2009 . Accounting Theory (Edisi Lima). Jakarta : Salemba Empat.

Hanafi, Mahmud dan Abdul Halim . 2016 . Analisis Laporan Keuangan (Edisi Kelima) . Yogyakarta : UPP STIM YKPN .

Handoko, Hani . 2014 . Manajemen Personalia \& Sumberdaya Manusia (Edisi Dua ). Yogyakarta : BPFE Yogyakarta .

Ikatan Akuntan Indonesia . 2015 . Standar Akuntansi Keuangan . Jakarta : Salemba Empat

Ikhsan, Arfan . 2008 . Akuntansi Sumberdaya Manusia . Yogyakarta : Graha Ilmu

Ikhsan, Arfan dan Ishak Muhammad . 2008 . Akuntansi Keperilakuan . Jakarta : Salemba Empat .

Kasmir . 2010 . Pengantar Manajemen Keuangan . Jakarta : Kencana .

Kieso, Donald E dkk . 2008 . Akuntansi Intermediate (Jilid 1 Edisi Keduabelas) . Jakarta : Erlangga .

Lusyningtyas, Ety . 2016 . Analisis Akuntansi Sumber Daya Manusia dengan Akuntansi Konvensional dan Pengaruhnya Terhadap Laporan Keuangan Pada PT. PPILN Area Kediri . Kediri : Universitas Islam Kadiri .

Namudani, Yana Putri . 2015 . Pengaruh Perputaran Modal Kerja Terhadap Kinerja Keuangan Pada Koperasi Al-Amin Wahidiyah Kediri . Kediri : Universitas Islam Kadiri .

Ndraha, Taliziduhu . 2012 . Pengantar Teori Pengembangan Sumber Daya Manusia . Jakarta : Rineka Cipta .

Putro, Adnan . 2016 . Penerapan Kapitalisasi Biaya Sumber Daya Manusia Pada Penyajian Laporan Keuangan (Study Kasus PT. Brantas Abipraya Persero). Kediri : Universitas Islam Kadiri .

Sugiri, Slamet dan Sumiyana. 2009 . Akuntansi Keuangan Menengah (Buku 1 Edisi Revisian). Yogjakarta : UPP AMP YKPN. 
Sucipto. (2008). Penilaian Kinerja Keuangan Jurnal Akuntansi, Program Sarjana Universitas Sumatera, Medan.

Tunggal, Amin Widjaja . 2008 . Akuntansi Sumber Daya Manusia . Jakarta : Rineka Cipta 